\title{
PROTOZOOPLANKTON CHARACTERIZATION OF TWO CONTRASTING SITES IN A TROPICAL COASTAL ECOSYSTEM (GUANABARA BAY, RJ)
}

\author{
Eli Ana Traversim Gomes ${ }^{1}$, Viviane Severiano dos Santos $^{2,3}$, Denise Rivera Tenenbaum ${ }^{2}$ \& Maria Célia Villac ${ }^{4}$ \\ ${ }^{1}$ Universidade do Grande Rio José de Souza Herdy \\ Instituto de Biociências \\ (Rua Prof. José de Souza Herdy, 1160, 25071-200 Duque de Caxias, RJ, Brasil)
}

${ }^{2}$ Universidade Federal do Rio de Janeiro

Instituto de Biologia, Departamento de Biologia Marinha

(Cidade Universitária, CCS-A, 21941-590 Rio de Janeiro, RJ, Brasil)

${ }^{3}$ Habtec Engenharia Ambiental

(Av. Treze de Maio, 13/1508, 20031-901 Rio de Janeiro, RJ, Brasil)

${ }^{4}$ Universidade de Taubaté, Centro de Ciências Biológicas e de Saúde

Departamento de Biologia

(Campus do Bom Conselho, Praça Marcelino Monteiro, 63, 12030-010 Taubaté, SP, Brasil)

\section{A B S TR A C T}

Much time and resources have been invested in understanding plankton dynamics in Guanabara Bay (Brazil), but no attention has been devoted to the protozooplankton. To fulfill this lacuna, abundance and composition of protozooplankton were investigated from January to December - 2000 in fortnightly surface water samplings at two distinct water quality sites (Urca - closer to the bay entrance, more saline and cleaner waters; Ramos - inner reaches, hypereutrophic waters). The density at Urca $\left(10^{3}-10^{5}\right.$ cell. $\left.1^{-1}\right)$ was one to three orders of magnitude lower than at Ramos $\left(10^{4}-10^{5}\right.$ cell. $\left.1^{-1}\right)$. A seasonal trend for nanoplankton and protozooplankton was more evident at Urca, but both sites had lower densities during the colder period. Small heterotrophic dinoflagellates $(20-30 \mu \mathrm{m})$ were dominant in over $50 \%$ of the samples. The protozooplankton abundance and composition reflected the distinct trophic conditions states found at the bay. During the wet-warm season, non-oligotrich ciliates were representative of Ramos site with Gymnodiniaceae dinoflagellates, while tintinnids and heterotrophic dinoflagellates were predominantly found at Urca mainly during the dry-cold season. This first descriptive study towards the understanding of the intricate relationships among the microbial food web components reveals that protozooplankton can be a good indicator of water quality conditions at the bay.

\section{RESUMO}

Muito tem sido investido para entender a dinâmica do plâncton da Baía de Guanabara (Brasil), estuário tropical com sérios problemas ambientais, mas pouco se sabe sobre o protozooplâncton. Preenchendo esta lacuna, a composição e abundância do protozooplâncton (ciliados, flagelados heterotróficos) foram investigadas em 2000, por meio de amostragens subsuperficiais, quinzenais, em dois locais com qualidade distinta de água (Urca - entrada da baía, águas mais salinas e limpas; Ramos - região mais interna, águas hipereutróficas e menos salinas). A densidade na Urca $\left(10^{3}-10^{5}\right.$ cel. $\left.\mathrm{L}^{-1}\right)$ foi inferior à de Ramos $\left(10^{4}-10^{5}\right.$ cel. $L^{-1}$ ), com sazonalidade para o nanoplâncton e protozooplâncton mais evidente, menores valores durante o período mais frio (abril a agosto). Pequenos dinoflagelados $(20-30 \mu \mathrm{m})$ dominaram mais de $50 \%$ das amostras. A abundância e composição refletiram o distinto estado trófico na baía (análise fatorial de correspondência: 56\%). Ciliados não oligotríqueos (Vorticellidae, Dysteriidae, Didiniidae) e Gymnodiniaceae foram representativos de Ramos na estação quente-úmida (outubro - março), enquanto tintinídeos (Codonellopsidae, Metacyclididae, Tintinnidae, Undellidae) e dinoflagelados (Oxyphysaceae, Ebriidae, Protoperidiniaceae, Noctilucaceae) representativos da Urca, principalmente na estação fria-seca (abril - setembro). Este primeiro estudo descritivo, fundamental para o entendimento das relações na teia alimentar microbiana, revelou o protozooplâncton como bom indicador das condições da qualidade da água da baía.

Descriptors: Protozooplankton, Ciliates, Heterotrophic Flagellates, Tropical system, Guanabara Bay. Descritores: Protozooplâncton, Ciliados, Flagelados heterotróficos, Ecossistema tropical, Baía de Guanabara. 


\section{INTRODUCTION}

The first systematic, descriptive and comprehensive surveys to investigate the composition of the microplankton of Guanabara Bay (Rio de Janeiro, Brazil) were carried out early in the $20^{\text {th }}$ century (Faria \& Cunha, 1917; Cunha, 1922). These detailed qualitative assessments included various taxonomic groups that are presently dealt with separately such as zooplankton, protozooplankton, phytoplankton and cyanobacteria.

The distintion of the microplankton into diferent compartments of study, protozooplankton and phytoplankton, has been determined not only by methodological constraints, especially due to differences in size, but mostly because of the function that each group was believed to have in the food web. However, the better understanding about the roles of bacteria, phytoplankton and protozoans in the marine microbial loop (Pomeroy, 1974; Azam et al., 1983; Sherr \& Sherr, 1988) and the use of epifluorescence microscopy allowing the differentiation of true autotrophic protists, brought zoologists, phycologists and microbiologists back to close co-operation.

The biology of protozoan cells is well studied, but only studies after the 80 's have considered their importance in trophic dynamics of pelagic systems, as key organisms connecting the microbial loop with the classical food chain. Heterotrophic nanoflagellates were considered the major picoplankton consumers in oceanic waters (Andersen \& Fenchel, 1985), although Rivier et al. (1985) showed that the grazing of ciliates could be at times more important. Protozoans are also consumers of organic matter (Javornick \& Prokesová, 1963) and phytoplankton (Brook, 1952; Sherr \& Sherr, 1988).

In Brazilian waters, composition and spacetime variations of marine protozooplankton populations are poorly understood relatively to other plankton organisms, comprising only $4 \%$ of all publications (Brandini et al., 1997). Most studies are non- published data (thesis and reports) and focus on check-lists and taxonomic aspects of some groups, especially those that have a loricae or skeleton such as tintinnids, foraminifers and radiolarians. Few published surveys include quantitative aspects and are restricted to tintinnids (Sassi \& Melo, 1989; 1991; Cordeiro \& Sassi, 1997; Fernandes \& Brandini, 1999; Sassi et al., 1999; Fernandes, 2004a; 2004b). Phytoplankton studies are better represented (34\%), but they include a large number of species known to be mixotrophs and absolute heterotrophs, especially among dinoflagellates, as in most marine plankton studies from other parts of the world.
Our goal is to present the abundance and composition of the protozooplankton populations of Guanabara Bay in two sites with different organic conditions, taking into account the heterotrophic dinoflagellates traditionally considered as part of the phytoplankton.

\section{Study Area}

Guanabara Bay (Fig. 1), located in a humid tropical region $\left(43^{\circ} \mathrm{W}, 23^{\circ} \mathrm{S}\right)$, is known for its beauty and for its historic and socio-economic importance, but it is presently under severe antrophogenic eutrophication. With an area of $381 \mathrm{~km}^{2}$, volume of 2.0 $\mathrm{x} 10^{9} \mathrm{~m}^{3}, 35$ rivers and streams drainage and a semi-diurnal tide (average height $0.7 \mathrm{~m}$, Kjerfve et al., 1997), the water quality of this estuarine bay undergoes increasing deterioration since the early 80's (Feema, 1998). High input of in natura sewage (BOD 470 tons/day) and industrial wastes (150 tons/day), including those from the Duque de Caxias Oil Plant (REDUC), have contributed to the eutrophication of the bay (Lavrado et al., 1991; Paranhos et al., 2001).

Eutrophication levels vary from place to place (Mayr et al., 1989). Figure 1 shows the design of the bay where the best water quality is found closer to the entrance (Urca site), under the influence of more saline waters (32 -37) from the continental shelf that favors an efficient circulation. On the other hand, the worst condition is detected in the inner area of the western portion (Ramos site), with less saline waters (13 - 29), where landfills have hampered the diluting capacity of the tidedriven circulation.

Despite better conditions in Urca site, according to Paranhos et al. (2001) its waters are considered eutrophic (Table 1), while waters in Ramos site are considered hypereutrophic.

Plankton dynamics in Guanabara Bay showed temporal trends associated to seasonal variations determined by a rainy summer and spatial trends associated to a tide-induced current pattern that create horizontal and vertical gradients (Valentin et al., 1999). Bacterioplankton was abundant during $1998 \quad\left(10^{3}\right.$ $\left.\mu \mathrm{gC} . \mathrm{L}^{-1}\right)$, while phytoplankton, represented by several taxonomic groups, was dominated by nanoplankton (autotrophic flagellates and diatoms) and filamentous cyanobacteria (Tenenbaum et al., 2001). Zooplankton, with several sensitive species to poor water quality and salinity gradients, decreased or disappeared at the inner reaches and in more impacted areas (Valentin et al., 1999). 

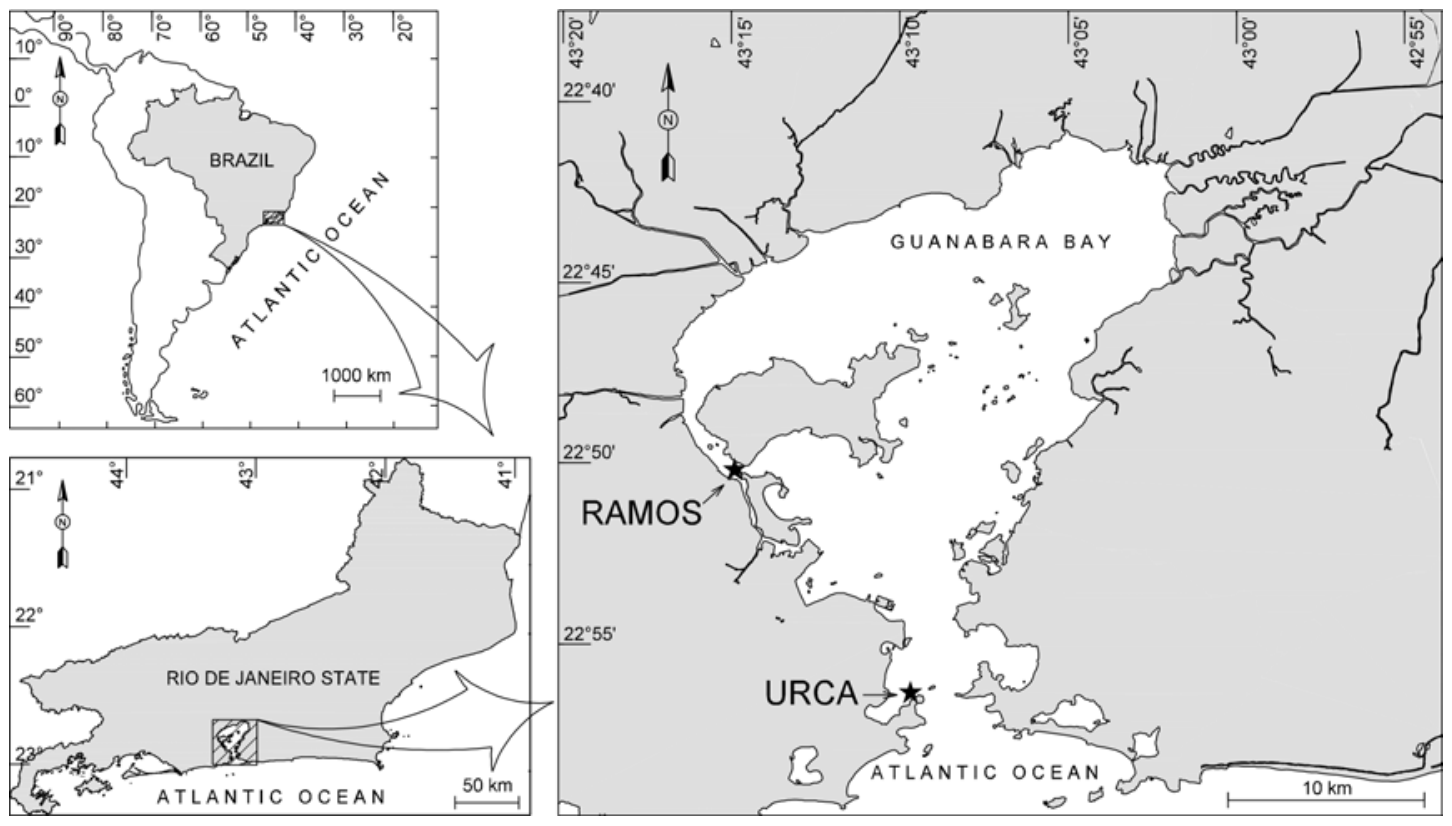

Fig. 1. Guanabara Bay, Rio de Janeiro, Brazil, showing the sampling sites ( $\star$ ).

Table 1. Minimun and maximum concentrations of chlorophyll $a$ and dissolved nutrients at Urca and Ramos in Guanabara Bay.

\begin{tabular}{lcccc}
\hline \hline & \multicolumn{2}{c}{ Urca } & \multicolumn{2}{c}{ Ramos } \\
& minimum & maximun & minimum & maximun \\
\hline Chlorophyll $a\left(\mu{\left.\mathrm{g} . \mathrm{L}^{-1}\right)}^{-1}\right.$ & 0.00 & 58.24 & 7.26 & 483.50 \\
Ammonia $(\mu \mathrm{M})$ & $<0.05$ & 28.99 & 1.44 & 62.70 \\
Total nitrogen $(\mu \mathrm{M})$ & 0.65 & 68.28 & 5.00 & 346.30 \\
Total phosphorus $(\mu \mathrm{M})$ & 0.05 & 7.39 & 0.22 & 26.42 \\
Silicate $(\mu \mathrm{M})$ & 0.40 & 60.99 & 5.43 & 176.80 \\
\hline
\end{tabular}

Data from: Paranhos et al. (2001)

\section{Material and Methods}

From January to December 2000, samples were fortnightly taken at the two sites Urca and Ramos (Fig. 1): Site Urca - more saline and cleaner water from continental shelf, and site Ramos - less saline waters due to the proximity to rivers and waste outfalls. Sub-surface water samples were collected with a Van Dorn bottle, fixed with sodium tetraborate buffered formaldehyde ( $2 \%$ final concentration) to minimize $\mathrm{pH}$ shift in the samples and preserve $80-90 \%$ of cells, then stored at $4^{\circ} \mathrm{C}$ (Sherr \& Sherr, 1993).

Protozooplankton (heterotrophic dinoflagellates, other flagellates and ciliates) from microplanktonic
(> $20 \mu \mathrm{m}$ - Sieburth et al., 1978) classification, was analyzed by the settling technique (Utermöhl, 1958) using different volumes: $50 \mathrm{~mL}$ for ciliates and $2-50$ $\mathrm{mL}$ for others. Samples were analyzed with light microscopy (200 $\mathrm{x}$ magnifications) using a combination of bright field, phase contrast and epifluorescence illumination. Bright field and phase contrast gave the best results for ciliates. The size of cells was determined during the counting procedure. Epifluorescence was necessary to distinguish the heterotrophic flagellates (dinoflagellates and other groups) from usual autotrophic phytoplankton (Booth, 1987; 1995). "In vivo" samples were observed to help the identification of ciliates. 
To understand the protozooplankton food supply we analyzed the total nanoplankton $(2-20$ $\mu \mathrm{m})$. Five milliliter of formalin water sample was dyed with DAPI fluorochrom (4'6-diamidino-2phenilindol) at final concentration $0.5 \mu \mathrm{g} . \mathrm{L}^{-1}$, filtrated onto $1.0 \mu \mathrm{m}$ black polycarbonate membranes (Nuclepore ${ }^{\circledR}$ ) and mounted on permanent slides (Porter \& Feig, 1980; Crumpton, 1987). These slides were placed dark box in a refrigerator $\left(4-10^{\circ} \mathrm{C}\right)$ for one week and later stored in a freezer $\left(-20^{\circ} \mathrm{C}\right)$ until analyzes with epifluorescence microscopy (1000x magnification) under UV incident light were performed, when 400 organisms were counted in random fields.

Using Statistics ${ }^{\circledR} 6.0$ for Windows a nonparametric correlation and factorial analysis were carried out. The possibility of nanoplankton grazing by protozooplankton was verified with Spearman correlations; and to address which protozooplankton taxonomic categories were most important at the two study sites with different water quality conditions, factorial correspondence analysis was conducted on a standardized matrix $(\log x+1)$ of 32 taxonomic categories densities (variables) and 48 samples (cases).

\section{RESUlts}

The number of protozoans at Urca $\left(2.23 \times 10^{3}\right.$ to $1.45 \times 10^{5}$ cell. $^{-1}$ ) was one to two orders of magnitude lower than that at Ramos $\left(5.41 \times 10^{4}\right.$ to $6.14 \times 10^{5}$ cell. $^{-1}$ ) (Fig. 2). The same trend was observed for total nanoplankton (Urca $4.16 \times 10^{4}$ to $9.78 \times 10^{5}$ cell. $^{-1}$; $1.71 \times 10^{5}$ to $3.00 \times 10^{7}$ cell. $\left.^{-1}\right)$. A seasonal variation was observed with lower densities during the colder and drier period (June to September). This trend was more evident at Urca, where lower densities were observed from April to August, while specific oscillations disrupted the pattern observed at Ramos. In general, at Urca, the temporal variation of total nanoplankton and total protozooplankton was similar, while at Ramos this trend was not observed.

The ciliates (average $10^{4}$ cell. $^{-1}$ ) were less abundant than the dinoflagellates (average $10^{4}$ cell. $^{-1}$ at Urca, $10^{5}$ cell. $^{-1}$ at Ramos), but they accounted for almost $100 \%$ of total density in few occasions. Higher concentrations of ciliates at Urca were found in September, November and December and at Ramos in March and September, when the former also coincided with low nanoplankton densities $(5-20 \mu \mathrm{m})$ (Fig. 2).

Total nanoplankton showed significant correlations at Urca with total ciliates $(r=0.41, p=0.05)$ and the families Dysteriidae $(\mathrm{r}=0.51, \mathrm{p}=0.01)$, Mesodiniidae $(r=0.45, p=0.03)$, Tetrahymenidae $(r=$ $0.44, p=0.03$ ) included in Hymenostomatida, and Tintinnidiidae $(\mathrm{r}=0.61 ; \mathrm{p}=0.001)$, while at Ramos significant correlations were observed only with Mesodiniidae $(\mathrm{r}=0.78, \mathrm{p}=0.000008)$ and Xystonellidae $(\mathrm{r}=0.47, \mathrm{p}=0.02)$.
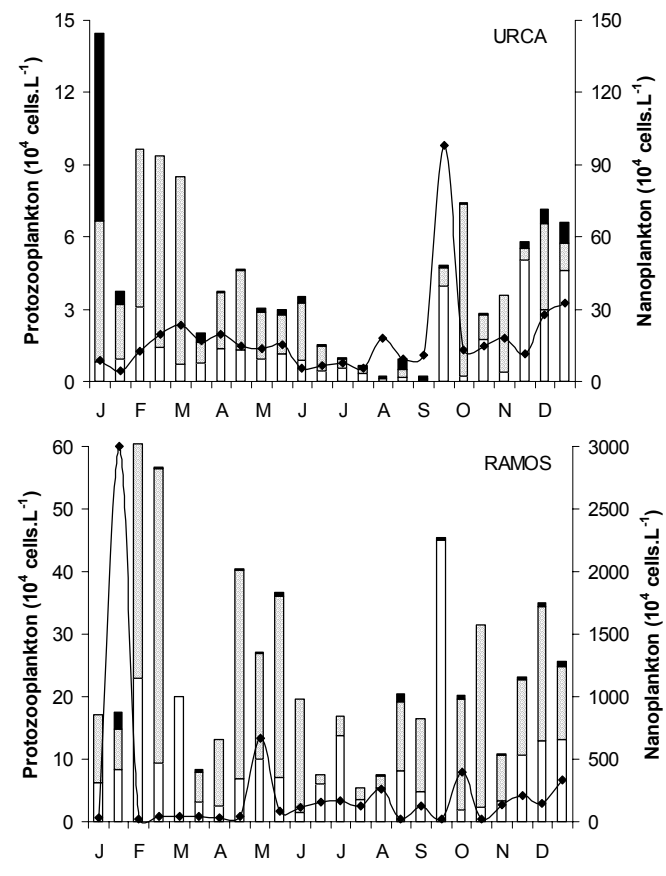

$\square$ Ciliates $\square$ Dinoflagellates $\square$ Flagellates $\rightarrow$ Nanoplankton

Fig. 2. Protozooplankton categories and nanoplankton abundances, from January to December 2000 in Guanabara Bay.

Heterotrophic dinoflagellates dominated in $58 \%$ of Urca samples ( 2 to 31 times as many ciliates) and in $67 \%$ of Ramos samples (up to 13 times as many ciliates). The dinoflagellates dominance was more conspicuous during the summer (February-March) and early autumn, while the relative abundance of ciliates was higher mainly from winter to late spring. Other flagellates represented a small percentage of the total density, especially at Ramos $(0-15 \%)$, but they reached $54 \%$ at Urca in January.

The ratio between microzooplankton (protozoans) and nanoplankton $(\mathrm{M} / \mathrm{N})$ indicated trophic relationship envolving both communities. $\mathrm{M} / \mathrm{N}$ ratio was higher at Ramos ( 0.60 to 2.36$)$ than at Urca (0.01 to 1.66) (Fig. 3). The microzooplankton predation upon nanoplankton $(\mathrm{M} / \mathrm{N}>1.0)$ demonstrated seasonal variation, because ratios were minor during dry-cold period (April-August) and larger during wet-warm period (January-March, September-October).

The protozooplankton organisms belonged to various classes of ciliates and flagellates and they were grouped in 25 families (Table 2) and two orders (Prostomatida and Hymenostomatida). The order Hymenostomatida included two genera probably of the family Tetrahymenidae. Several unidentified flagellates were grouped in an arbitrary category. 


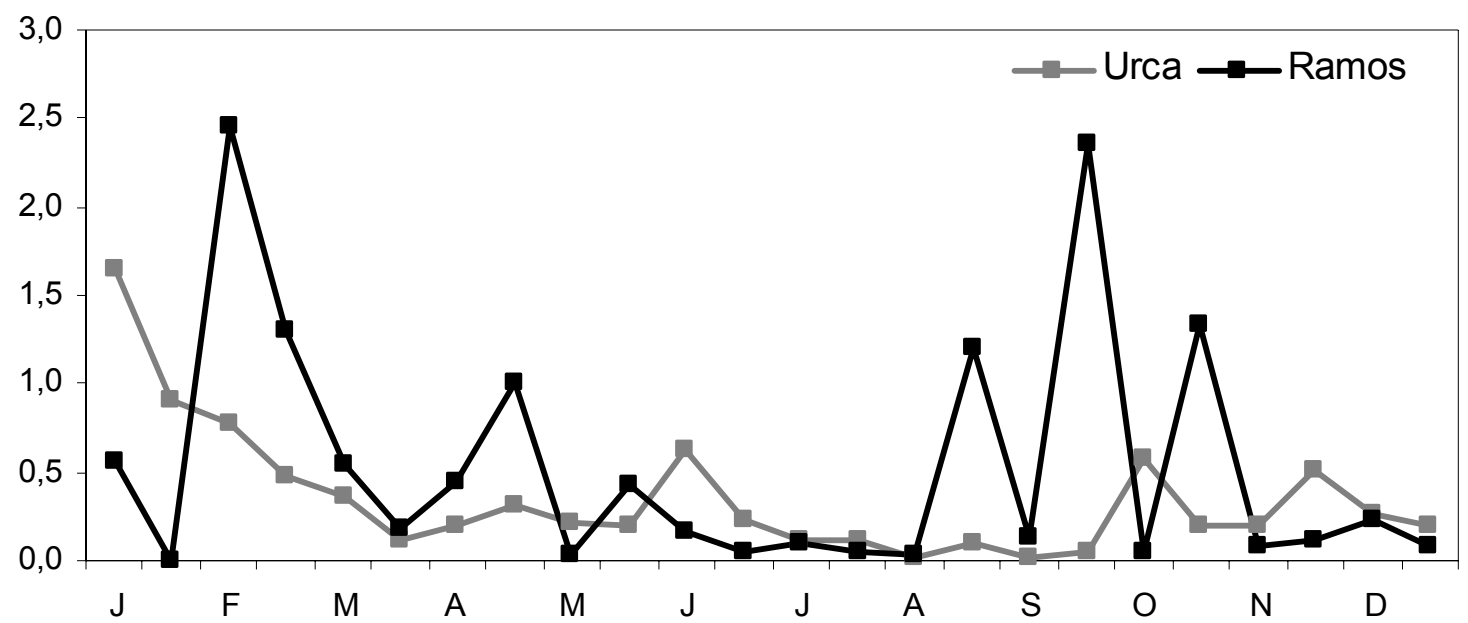

Fig. 3. Ratio between microzooplankton and nanoplankton (M/N) in Guanabara Bay, from January to December 2000.

The categories considered constant $(>81 \%$ occurrence) or frequent (51-80\% occurrence) were Gymnodiniaceae and Protoperidiniaceae from dinoflagellates, Hymenostomatida, Halteriidae, Euplotidae, Didiniidae, Mesodiniidae and Strombidiidae from ciliates, and unidentified flagellates (Table 2). The organisms that determined these high frequencies at Urca were the dinoflagellates Gymnodinium/Gyrodinium complex and Protoperidinium cf. pellucidum, and ciliates Halteria spp., Euplotes charon, Didinium sp., Mesodinium sp., Strombidium sulcatum and Strombidium compressum. At Ramos, the most frequent organisms were Halteria spp. and Euplotes charon, reaching 100\% occurrence, as well as the Gymnodinium/Gyrodinium complex, Protoperidinium cf. conicum, Euplotes harpa, Didinium sp. and Mesodinium sp.

The tintinnids, present at Urca with 17 species and at Ramos with 10 species, were constant or frequent only at Urca (Table 2). The families found were: Codonellidae, Codonellopsidae, Metacyclididae, Ptychocylididae, Tintinnidae, Tintinnidiidae, Undellidae, and Xystonellidae. Undella hyalina was the most frequent tintinnid (Urca - 88\%; Ramos $38 \%$ ) during the study period.

Organisms were also analyzed by size classes (Fig. 4), which can reflect their role in trophic dynamics. At both sites, the 20-40 $\mu \mathrm{m}$-size class was the most important $(>80 \%)$, followed by the $41-60 \mu \mathrm{m}$ size class $(<11 \%)$. The larger size classes together $(61-100 \mu \mathrm{m},>101-200 \mu \mathrm{m})$ represented $4 \%$ at both stations, but the largest species were found at Urca only, mainly the tintinnids Helicostomella spp. (165 $\mu \mathrm{m})$ and Eutintinnus fraknoi $(200 \mu \mathrm{m})$, and the dinoflagellate Noctiluca scintillans $(200 \mu \mathrm{m})$.
The composition of the dominant size class was similar at Urca and Ramos, although the relative abundances of the organisms were slightly different. At Urca, the dinoflagellates Gymnodiniaceae (31\%), Ebriidae (Ebria tripartita) (18\%) and Protoperidiniaceae $(15 \%)$ were more abundant than the ciliates (14\%) Halteriidae (4\%), Hymenostomatida (4\%) and other non-tintinnids ciliates (6\%). At Ramos, the dinoflagellates proportions were similar (Gymnodiniaceae 36\%, Protoperidiniaceae 14\%, Oxyphysaceae (Oxyphysis oxytoxoides) 2\%), but the proportions of ciliates increased $(22 \%)$ mainly Halteriidae $(7 \%)$ and other non-tintinnids ciliates $(11 \%)$. Other heterotrophic flagellates $(20-40 \mu \mathrm{m})$ were present in similar relative abundance at Urca (4\%) and Ramos (2\%). The second dominant size class $(41-60 \mu \mathrm{m})$ represented $8 \%$ at Urca and $10 \%$ at Ramos, with different relative abundance of ciliates (8\% at Urca and $6 \%$ at Ramos) and Gymnodiniaceae dinoflagellates found only at Ramos (5\%).

The factorial correspondence analysis explained $56 \%$ of data variance (Fig. 5), demonstrating that the quantitative variations were represented by factor I where the highest densities of total nanoplankton at Ramos site were isolated at the positive side mainly in January 19 and August 04. All of the categories (ciliates, dinoflagellates and flagellates) with lower densities, compared with total nanoplankton, were positioned at the negative side, with best representation of Vorticellidae ciliates at Ramos and Codonellopsidae ciliates and dinoflagellates from families Oxyphysaceae, Noctilucaceae and Protoperidiniaceae at Urca site. 
Table 2. Occurrence of the protozooplankton found at Urca and Ramos in Guanabara Bay, from January to December 2000 ( $\mathrm{n}=24$ samples for each site): Rare $(\mathrm{R}) \leq 10 \%$; Present (P) $>11 \%$ and $\leq 50 \%$; Frequent $(\mathrm{F})>51$ and $\leq 80 \%$; Constant (C) $>81 \%$.

\begin{tabular}{|c|c|c|}
\hline & Urca & Ramos \\
\hline \multicolumn{3}{|l|}{ Dinoflagellates } \\
\hline Ebriidae & $F^{*}$ & $\mathrm{P}^{*}$ \\
\hline Gymnodiniaceae & $C^{* *}$ & $C^{* * *}$ \\
\hline Noctilucaceae & $\mathrm{P}$ & \\
\hline Oxyphysaceae & $\mathrm{P}^{*}$ & $\mathrm{~F}^{* *}$ \\
\hline Protoperidiniaceae & $\mathrm{F}^{*}$ & $\mathrm{~F}^{*}$ \\
\hline Other Flagellates & $\mathrm{C}^{* *}$ & $\mathrm{~F}^{*}$ \\
\hline \multicolumn{3}{|l|}{ Oligotrich Ciliates } \\
\hline Strombidiidae & $C^{*}$ & $\mathrm{~F}^{*}$ \\
\hline Codonellidae & $\mathrm{P}^{*}$ & $\mathrm{P}$ \\
\hline Codonellopsidae & $\mathrm{R}$ & \\
\hline Metacyclididae & $\mathrm{P}$ & $\mathrm{P}$ \\
\hline Ptychocylididae & $\mathrm{P}$ & $\mathrm{P}$ \\
\hline Tintinnidae & $\mathrm{F}^{*}$ & $\mathrm{R}$ \\
\hline Tintinnidiidae & $\mathrm{P}^{*}$ & $\mathrm{P}$ \\
\hline Undellidae & $C^{*}$ & $\mathrm{P}$ \\
\hline Xystonellidae & $\mathrm{P}$ & $\mathrm{P}$ \\
\hline \multicolumn{3}{|l|}{ Other Ciliates } \\
\hline Amphileptidae & $\mathrm{P}$ & $\mathrm{P}$ \\
\hline Colepidae & $\mathrm{F}^{*}$ & $\mathrm{P}$ \\
\hline Condylostomatidae & $\mathrm{P}$ & $\mathrm{R}$ \\
\hline Didiniidae & $\mathrm{F}$ & $\mathrm{F}$ \\
\hline Dysteriidae & $\mathrm{P}$ & $\mathrm{P}$ \\
\hline Euplotidae & $\mathrm{F}^{*}$ & $\mathrm{C}^{*}$ \\
\hline Halteriidae & $C^{*}$ & $\mathrm{C}^{*}$ \\
\hline Hymenostomatida & $\mathrm{C}^{*}$ & $\mathrm{C}^{*}$ \\
\hline Lembadionidae & $\mathrm{R}$ & $\mathrm{R}$ \\
\hline Mesodiniidae & $\mathrm{F}$ & $\mathrm{F}^{* *}$ \\
\hline Pleuronematidae & $\mathrm{P}^{*}$ & $\mathrm{~F}$ \\
\hline Prostomatida & $\mathrm{F}^{*}$ & $\mathrm{P}$ \\
\hline Vorticellidae & $\mathrm{P}^{*}$ & $\mathrm{P}^{*}$ \\
\hline
\end{tabular}

(*) at least one sample with density higher than the average density of the sample.

$(* *)$ at least one sample with density higher than $50 \%$ of total density of the sample. 

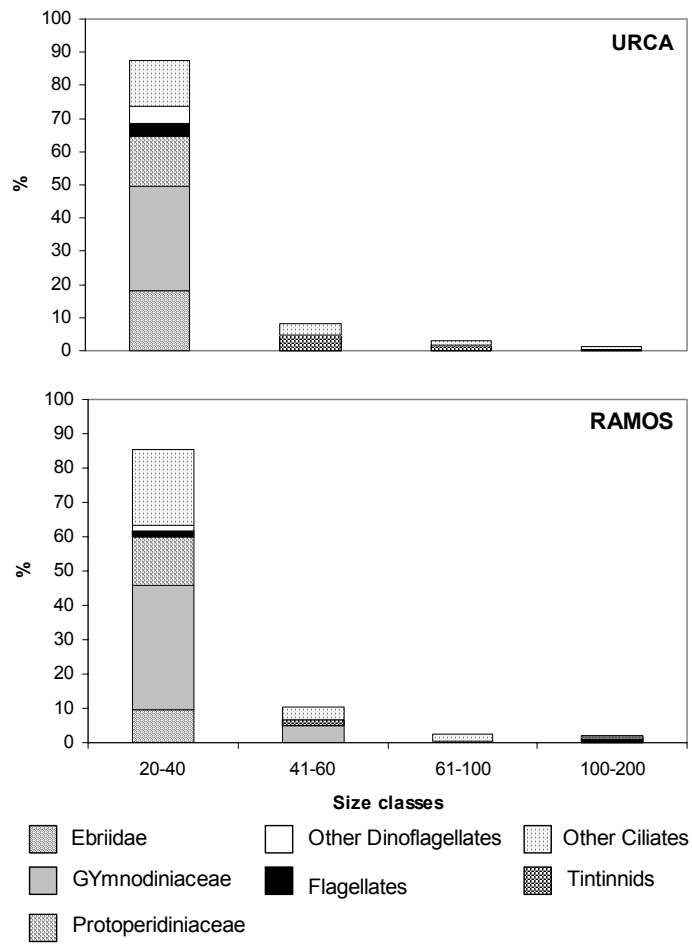

Fig. 4. Size-classes relative abundance of the protozooplankton in Guanabara Bay, from January to December 2000, based on the values of the median of each component.

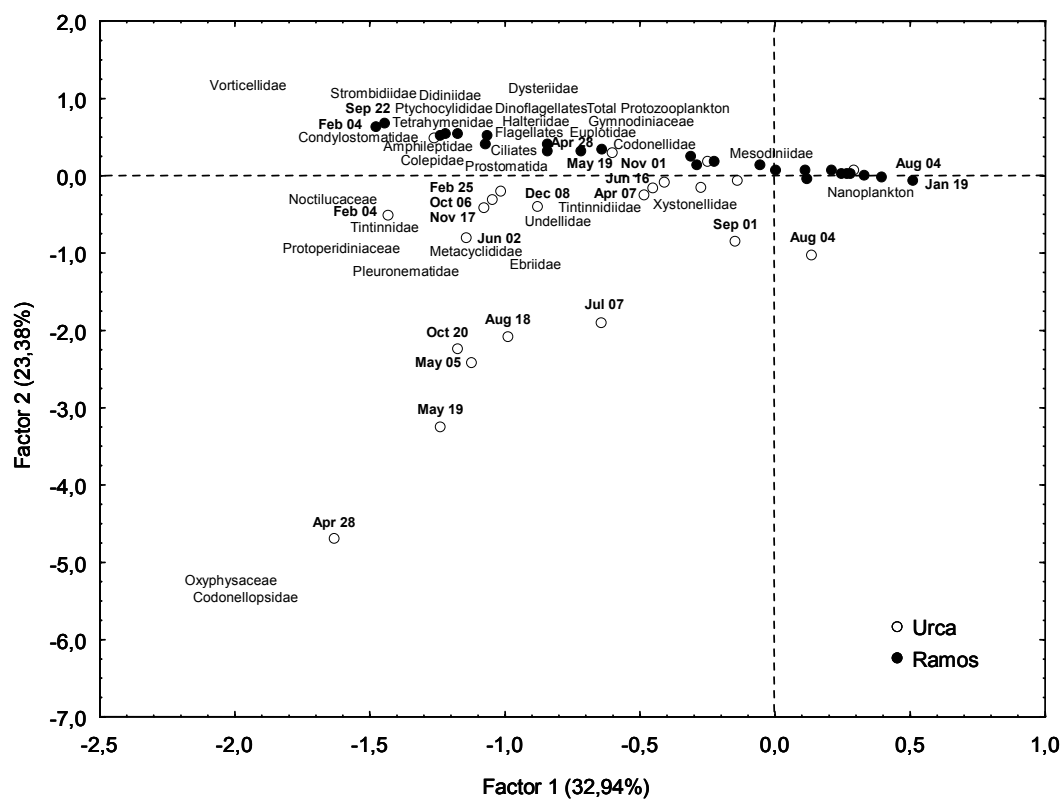

Fig. 5. Correspondence analyzes of 32 taxonomic categories (variables) of protozooplankton with 48 samples (cases) at site Urca and site Ramos in Guanabara Bay. 
Factor II was related with water quality, where at the positive side we found samples from Ramos site, the hypereutrophic conditions, mainly during the wet-warm season samples (October March) associated with most of non-oligotrich ciliates (Vorticellidae, Dysteriidae, Didiniidae, Tetrahymenidae, Halteriidae, Condylostomatidae, Euplotidae, Colepidae), four families of oligotrich ciliates (naked Strombidiidae and tintinnids Ptychocylididae, Codonellidae), Gymnodiniaceae dinoflagellates and other heterotrophic flagellates. On the oher hand, at the negative side were positioned samples from Urca site with best water quality conditions, essentially during the dry-cold season (April - September). Along with those better conditions we found the majority tintinnids (Codonellopsidae, Metacyclididae, Tintinnidae, Undellidae, Tintinnidiidae, Xystonellidae) and heterotrophic dinoflagellates (Oxyphysaceae, Ebriidae, Protoperidiniaceae, Noctilucaceae).

\section{Discussion}

Although ciliates and dinoflagellates were familiar organisms to microbiologist and naturalists in the early $19^{\text {th }}$ century, little is known about their population dynamics in marine environments. Since the very first check-list of protozoans of Guanabara Bay, a survey carried out in 1913 (Faria \& Cunha, 1917; Cunha, 1922), we present here the first quantitative results for the protozooplankton of the bay. Our study makes a few additions to the species check-list published by Faria \& Cunha (1917). The most frequent species found by the authors mentioned above were (nomenclature not updated): Cytarocylis ehrengergi var. adriatica, Tintinnopsis mortenseni, Tintinnopsis prowazeki, Tintinnopsis ventricosa, Tintinnus subulatus, Sticholonche zanclea, Ebria tripartita, Hermesinum adriaticum, Peridinium conicum, Peridinium depressum, Peridinium pentagonum, Peridinium steinii. At present, the most frequent taxa at Urca and/or Ramos are the ciliates Halteria spp., Euplotes charon, Didinium sp., members of order Hymenostomatida and Undella hyalina, and dinoflagellates members of the family Gymnodiniaceae. These differences can be an answer to the notable antropic eutrophication of Guanabara Bay. However, we must remember that methodological aspects, especially those related to the collection and preservation of samples, influence the results obtained. The sampling design at several sites performed by Faria \& Cunha (1917), associated with the use of nets of different mesh sizes allowed the selection of many more loricate ciliates and tecate flagellates against naked ciliates and atecate flagellates than our survey.

Pelagic microplanktonic marine ciliates are mostly composed by the radially symmetric oligotrichs, especially naked species. Among oligotrichs, however, the loricate tintinnids have received more attention because their loricae are more easily recognized, even on preserved samples. This leads to the erroneous idea that they can be more abundant than other protozooplankton organisms (Laybourn-Parry, 1992; Leakey et al., 1996). In fact, naked ciliates have been under-estimated in pelagic systems, and they can be 50 times more abundant than tintinnids (Smetacek, 1981; D'Alcalà et al., 2004).

Protozooplankton abundance at Guanabara Bay $\left(10^{3}-10^{5}\right.$ cells. $\left.L^{-1}\right)$ is similar to that found in eutrophic systems in Brazil, such as freshwater lakes (Gomes \& Godinho, 2003) and coastal lagoon (Odebrecht, 1988) that considered both naked and loricate ciliates. In contrast, protozoan abundance in offshore waters of the western South Atlantic Ocean (Tenenbaum et al., 2001) was lower than that of Guanabara Bay, because their waters are oligotrophic (Silveira et al., 2000).

Like the other plankton components of Guanabara Bay (Valentin et al., 1999), the protozooplankton showed a seasonal variation with lower densities during the colder and dryer season (winter). Nevertheless, this seasonality was more clearly marked at Urca than at Ramos, probably because Ramos is more unstable since the inner reaches of the bay are subjected to the alternate influence of domestic and industrial waste inputs and cleaner saline waters during high spring tides (Mayr et al., 1989).

Protozooplankton composition and abundance found at Urca and at Ramos reflected the horizontal trophic conditions and salinity gradients at Guanabara Bay, and therefore, they can be used as an indicator of water quality for monitoring purposes.

The higher protozooplankton abundance found at Ramos is probably associated with top-down pressure upon bacteria, since it coincided with higher nanoplankton observed at the same period. The trophic conditions of the study sites can be established based on chemical parameters, bacterial abundance and their metabolic activity: Urca has the best (eutrophic) and Ramos has the worst (hypereutrophic) water quality scenarios, where bacterioplankton populations are under, bottom-up and top-down controls, respectively (Paranhos et al., 2001).

The dominance of naked ciliates (non oligotrichous) at both sites, especially in Ramos, also reflects the higher eutrophication of the inner reaches of the bay. A similar pattern was found in the tropical waters of the Indian Ocean: higher ciliate biomass was associated with regions of enhanced productivity, where naked ciliates reached up to $99 \%$ of total protozoans as opposed to tintinnids that remained under $21 \%$ of the community (Leakey et al., 1996). The higher tintinnids frequency and species number found at Urca can be 
attributed to a better affinity of this group to more saline waters (Alder, 1999).

The influence of the trophic state on the protozooplankton has been pointed out for other environments (Beaver \& Crisman, 1989; Hwang \& Heath, 1997). At the species level, several organisms are considered good indicators of the distinct conditions found between sampling sites. Small organisms (e.g., dinoflagellates Gymnodinium/ Gyrodinium complex and Protoperidinium conicum, and ciliates Halteria spp., Euplotes charon), although present at both sites, predominated at the stressful conditions of Ramos (Table 2). Typically small and large marine species (e.g., Protoperidinium cf. pellucidum, Noctiluca scintilans, Codonellopsis sp., Steenstrupiella sp., Eutintinnus cf. fraknoi, and Helicostomella spp.), were found only at Urca.

Heterotrophic dinoflagellates were numerically more important than the ciliates of Guanabara Bay, as observed elsewhere (Fenchel, 1987; Laybourn-Parry, 1992; Levinsen \& Nielsen, 2002). Nevertheless, the knowledge on population dynamics of tropical planktonic heterotrophic dinoflagellates is poorly understood. The great contribution of heterotrohic dinoflagellates to overall ciliated protozoan density demonstrates the importance of using epifluorescence microscopy in routine analysis. The reallocation of these "phytoplankton" species to the protozooplankton, associated with pico- and nanoplankton studies, is a key to the understanding of trophodynamic of the planktonic microbial food web in the bay.

\section{AcKNowledgements}

We are indebted to all those who made countless hours of field work possible and enjoyable. We are also grateful Dr. Jean Louis Valentin for coordination of the project and Leonardo de S. Dias for design of Figure 1. Finally, support was provided by the following funding agencies: MCT/MEC (Pronex), $\mathrm{CNPq}$ and PIBIC/UFRJ (fellowships to M.C.V. and V.S.S.).

\section{REFERENCES}

Alder, V. A. 1999. Tintinnoinea. In: Boltovskoy, D., ed. South Atlantic Zooplankton. Leiden: Backhuys Publishers, v.1, p.321-384.

Andersen, P. \& Fenchel, T. 1985. Bacterivory by microheterotrophic flagellates in seawater samples. Limnol. Oceanogr., 30:198-202.

Azam, F.; Fenchel, T.; Field, J. G.; Gray, J. S.; Meyer-Reil, L. A. \& Thingstad, F. 1983. The ecological role of water-column microbes in the sea. Mar. Ecol. Prog. Ser., 10:257-263.
Beaver, J. R. \& Crisman, T. L. 1989. Analysis of the community structure of planktonic ciliated protozoa relative to trophic state in Florida lakes. Hydrobiologia, 174:177-184.

Booth, B. C. 1987. The use of autofluorescence for analysing oceanic phytoplankton communities. Bot. mar., 30:101108.

Booth, B. C. 1995. Estimacion de la biomasa del plancton autotrofico usando microscopia. In: Alveal, K., Ferrario, M. E., Oliveira, E. C. \& Sar, E., eds. Manual de Metodos Ficologicos. Universidad de Concepcion, Chile. p.187-198.

Brandini, F. P.; Lopes, R. M.; Gutseit, K. S.; Spach, H. L. \& Sassi, R. 1997. Planctonologia na plataforma continental do Brasil - Diagnose e revisão bibliográfica, Avaliação do potencial sustentável de recursos vivos na Zona Econômica Exclusiva. MMA/CIRM/Femar. 196 p.

Brook, A. J. 1952. Some observations on the feeding of Protozoa on freshwater algae. Hydrobiologia, 4:281-293.

Cordeiro, T. A. \& Sassi, R. 1997. Tintinnina (Ciliophora, Protista) of the North Sea during the spring of 1986. Helgoländer Meeresunters., 51:155-172.

Crumpton, W. G. 1987. A simple and reliable method for making permanent mounts of phytoplankton for light and fluorescence microscopy. Limnol. Oceanogr., 32:1154-1159.

Cunha, A. M. 1922. Estudos sobre Protozoários do mar. Mem. Inst. Oswaldo Cruz, 6:186-208.

D’Alcalà, M. R.; Conversano, F.; Corato, F.; Licandro, P.; Mangoni, O.; Marino, D.; Mazzocchi, M. G.; Modigh, M.; Montresor, M.; Nardella, M.; Saggiomo, V.; Sarno, D. \& Zingone, A. 2004. Seasonal patterns in plankton communities in a pluriannual time series at a coastal Mediterranean site (Gulf of Naples): an attempt to discern recurrences and trends. Sci. Mar., 68:65-83.

Faria, J. G. \& Cunha, A. M. 1917. Estudos sobre o microplancton da baía do Rio de Janeiro e suas imediações. Mem. Inst. Oswaldo Cruz, 9:68-93.

FEEMA (Fundação Estadual de Engenharia e Meio Ambiente). 1998. Qualidade de água da Baía de Guanabara 1990/1997. Rio de Janeiro: FEEMA. 100 p.

Fenchel, T. 1987. Ecology of Protozoa. The biology of freeliving phagotrophic protests. Madison: Science Tech Publishers. 197p.

Fernandes, L. F. \& Brandini, F. P. 1999. Comunidades microplanctônicas no Oceano Atlântico Sul Ocidental: biomassa e distribuição em novembro de 1992. Revta. bras. Oceanogr., 47:189-205.

Fernandes, L. F. 2004a. Tintininos (Ciliophora, Tintinnida) de águas subtropicais na região Sueste-Sul do Brasil. I. Famílias Codonellidae, Codonellopsidae, Coxliellidae, Cyttarocylidae, Epiplocylidae, Petalotrichidae, Ptychocylidae, Tintinnidae e Undellidae. Rev. bras. Zool., 21:551-576.

Fernandes, L. F. 2004b. Tintininos (Ciliophora, Tintinnida) de águas subtropicais na região Sueste-Sul do Brasil. II. Famílias Dictyocystidae, Rhabdonellidae, Tintinnidae e Xystonellidae. Rev. bras. Zool., 21:605-628.

Gomes, E. A. T. \& Godinho, M. J. L. 2003. Structure of the protozooplankton community in a tropical shallow and eutrophic lake in Brazil. Acta Oecol., 24:S153-S161.

Hwang, S. J. \& Heath, R. T. 1997. The distribution of protozoa across a trophic gradient, factors controlling their abundance and importance in the plankton food web. J. Plankton Res., 19:491-518. 
Javornick, P. \& Prokesová, V. 1963. The influence of Protozoa and Bacteria upon the oxidation of organic substances in water. Int. Rev. Gesamten Hydrobiol, 48:335-350.

Kjerfve, B.; Ribeiro, C. H. A.; Dias, G. T. M.; Filippo, A. M. \& Quaresma, V. S. 1997. Oceanographic characteristics of an impacted coastal bay: Baía de Guanabara, Rio de Janeiro, Brazil. Continent. Shelf Res., 17:1609-1643.

Lavrado, H. P.; Mayr, L. M.; Carvalho, V. \& Paranhos, R. 1991. Evolution (1980-1990) of ammonia and dissolved oxygen in Guanabara Bay, RJ, Brazil. In: Magoon, O. \& Neves, C. eds. Coastlines of Brazil. New York: American Society of Civil Engineers,. p.3234-3245.

Laybourn-Parry, J. 1992. Protozoan plankton ecology. London: Chapman \& Hall, 231p.

Leakey, R. J. G.; Burkill, P. H. \& Sleigh, M. A. 1996. Planktonic ciliates in the northwestern Indian Ocean: their abundance and biomass in waters of contrasting productivity. J. Plankt Res., 18:1063-1071.

Levinsen, H. \& Nielsen, T. G. 2002. The trophic role of marine pelagic ciliates and heterotrophic dinoflagellates in artic and temperate coastal ecosystem: A cross-latitude comparison. Limnol. Oceanogr., 47:427-439.

Mayr, L. M.; Tenenbaum, D. R.; Villac, M. C.; Paranhos, R.; Nogueira, C. R.; Bonecker, S. L. C. \& Bonecker, A. C. T. 1989. Hydrobiological characterization of Guanabara Bay. Magoon, O. \& Neves, C. eds. Coastlines of Brazil. New York: American Society of Civil Engineers. p.124 138

Odebrecht, C. 1988. Variações espaciais e sazonais do fitoplâncton, protozooplâncton e metazooplâncton na Lagoa da Conceição, Ilha de Santa Catarina, Brasil. Atlântica, 10:21-40.

Paranhos, R.; Andrade, L.; Mendonça-Hagler, L. C. S. \& Pfeiffer, W. C. 2001. Coupling bacterial abundance with production in a polluted tropical coast bay. Oecol. Brasiliensis, 9:117-132.

Pomeroy, L. R. 1974. The ocean's food web: a chanching paradigm. BioScience, 24:499-504.

Porter, G. P. \& Feig, Y. S. 1980. The use of DAPI for identifying and counting aquatic microflora. Limnol. Oceanogr., 25:943-948.

Rivier, A.; Brownlee, D. C.; Sheldon, R. W. \& Rassoulzadegan, F. 1985. Growth of microzooplankton: a comparative study of bactivorous zooflagellates and ciliates. Mar. Microb. Food Webs, 1:51-60.

Sassi, R. \& Melo, G. N. 1989. Hyaline Tintinnina (ProtozoaCiliophora-Oligotrichida) from northeast Brazilian coastal reefs. Bol. Inst. Oceanogr., 37:59-74.
Sassi, R. \& Melo, G. N. 1991. Tintinnina (ProtozoaCiliophora-Oligotrichida) from the second Brazilian expedition to the Antarctic. Braz. J. Biol., 53:311-325.

Sassi, R.; Kutner, M. B. B. \& Pompeu, M. 1999. First record of the ciliate Eutintinnus apertus with the attached diatom Chaetoceros tetrastichon in neritic waters of southwestern atlantic. Rev. Nord. Biol., 13:47-60.

Sherr, E. B. \& Sherr, B. F. 1988. Role of microbes in pelagic food webs: a revised concept. Limnol. Oceanogr., 33:1225-1227.

Sherr, B. F. \& Sherr, E. B. 1993. Preservation and storage of samples for enumeration of heterotrophic protists. In: Kemp, P.F., Sherr, B.F., Sherr, E.B., Cole, J.J., ed. Handbook of methods in aquatic microbial ecology. Boca Raton, Fla.: Lewis Publishers. p.207-212.

Sieburth, J. McN.; Smetacek, V. \& Lenz, J. 1978. Pelagic ecosystem structure: heterotrophic compartments of the plankton and their relationship to plankton size fractions. Limnol. Oceanogr., 23:1256-1263.

Silveira, I. C. A.; Schmidt, A. C. K.; Campos, E. J. D.; Godoi, S. S. \& Ykeda, Y. 2000. A Corrente do Brasil ao largo da costa leste brasileira. Rev. bras. Oceanogr., 48:171-183.

Smetacek, V. 1981. The annual cycle of protozooplankton in the Kiel Bight. Mar. Biol., 63:1-11.

Tenenbaum, D. R.; Villac, M. C.; Gomes, E. A. T.; Cupelo, A. C. G. \& Santos, V. S. 2001. A new "sight" on microbial plankton ecology: coastal $\mathrm{x}$ oceanic system in Brazil. Oecol. Brazilienses, 9:133-152.

Utermöhl, H. 1958. Perccionamento del metodo cuantitativo del fitoplancton. Associación Internacional de Limnologia Teórica y Aplicada - Comité de metodos limnologicos, Comunicación, 9:1-39.

Valentin, J. L.; Tenenbaum, D. R.; Bonecker, A. C. T.; Bonecker, S. L. C.; Nogueira, C. R. \& Villac, M. C. 1999. O sistema planctônico da Baía de Guanabara. Síntese do conhecimento. Oecol. Brasiliensis, 7: 35-59.

(Manuscript received 16 December 2005; revised 31 July 2006; accepted 30 August 2006) 